\title{
IMPLEMENTASI LESSON STUDY DALAM UPAYA MENINGKATKAN KUALITAS PEMBELAJARAN KIMIA PADA MATERI HIDROLISIS GARAM DAN HASIL KALI KELARUTAN (Ksp) DI SMA NEGERI 7 TANGERANG
}

\author{
Muktiningsih Nurjayadi ${ }^{1}$, Sondang N. Sihombing ${ }^{1}$,Novi Permanasari ${ }^{1}$,Desi Lestari ${ }^{2}$ \\ ${ }^{1}$ Program studi Pendidikan Kimia, Jurusan Kimia, Fakultas Matematika dan IImu Pengetahuan \\ Alam Universitas Negeri Jakarta, Jl. Pemuda No. 10, Jakarta 13220, Indonesia \\ ${ }^{2}$ SMA Negeri 7 Tangerang, Indonesia \\ Corresponding author: mutinurjayadi@yahoo.com
}

\begin{abstract}
Abstrak
Penelitian ini bertujuan untuk meningkatkan kualitas pembelajaran kimia melalui Lesson Study pada materi Hidrolisis Garam, Kelarutan dan Hasil Kali Kelarutan (Ksp) di SMA Negeri 7 Tangerang. Metode penelitian yang digunakan dalam penelitian ini adalah Metode deskriftif kualitatif dengan pendekatan Active Learning. Penelitian dilakukan melalui enam kali pertemuan dengan empat siklus, dan setiap siklus terdiri dari tiga tahapan, yaitu tahap perencanaan (plan), tahap pelaksanaan $(d o)$, dan tahap refleksi (see). Selanjutnya pada tiap akhir materi pokok dilakukan tes hasil belajar.Kualitas pembelajaran pada penelitian ini diukur melalui empat indikator, yaitu interaksi siswa, motivasi belajar siswa, keaktifan siswa, dan keterlaksanaan proses pembelajaran oleh guru. Hasil analisis menunjukkan bahwa keempat indikator kualitas pembelajaran mengalami perubahan ke arah positif dari empat open lesson yang dilaksanakan. Berdasarkan hasil yang diperoleh dapat disimpulkan bahwa Lesson studydengan pendekatan active learning dapat meningkatkan kualitas pembelajaran kimia pada Materi Hidrolisis Garam, Kelarutan dan Hasil Kali Kelarutan (Ksp) di SMA Negeri 7 Tangerang.
\end{abstract}

Kata kunci

Kualitaspembelajaran, Active Learning, Lesson Study.

\section{Pendahuluan}

Ilmu kimia adalah ilmu yang mempelajari struktur, susunan, sifat, perubahan materi, dan energi yang menyertainya (Parning, 2000). IImu kimia berkaitan erat dengan kehidupan seharihari, seperti peristiwa pembakaran sampah, pembuatan sabun, dan sebagainya.Salah satu materi kimia yang dipelajari di tingkat SMA adalah hidrolisis garam dan kelarutan dan hasil kali kelarutan (Ksp). Karakteristik materi hidrolisis garam dan Ksp adalah lebih menekankan pada konsep dan perhitungan. Pada materi hidrolisis garam misalnya, penentuan jenis garam yang terhidrolisis dalam air dan penentuan $\mathrm{pH}$ larutan garam, sedangkan pada materi Ksp misalnya penentuan tetapan hasil kali kelarutan, penentuan $\mathrm{pH}$ larutan berdasarkan tetapan hasil kali kelarutan, dan memperkirakan terjadinya endapan berdasarkan tetapan hasil kali kelarutan. Berdasarkan hasil diskusi dengan guru di SMA Negeri 7 Tangerang, diperoleh informasi bahwa siswa merasa kesulitan terhadap materi hidrolisis garam dan Ksp yang ditandai dengan rata-rata perolehan hasil belajar siswa untuk materi hidrolisis garam sebesar 59,05 dan 60,57 untuk materi Ksp pada tahun ajaran 2007-2008. Hasil belajar yang diperoleh siswa masih di bawah standar KKM (Kriteria Ketuntasan Minimum) yaitu 65. 
Pada dasarnya, kualitas pembelajaran berkaitan erat dengan proses pembelajaran. Jika proses pembelajaran berjalan dengan baik, diharapkan kualitas pembelajaran juga akan baik. Pembelajaran adalah suatu sistem yang bertujuan untuk membantu proses belajar siswa yang berisi serangkaian peristiwa yang dirancang, disusun sedemikian rupa untuk mempengaruhi dan mendukung terjadinya proses belajar siswa yang bersifat internal (Gagne dan Briggs, dalam Senjaya, 2008). Proses belajar itu sendiri dapat dipahami sebagai tahapan perubahan seluruh tingkah laku individu yang relatif menetap sebagai hasil pengalaman dan interaksi dengan lingkungan yang melibatkan proses kognitif (Syah, 2008). Pengkajian pembelajaran sangat diperlukan untuk meningkatkan kualitas pembelajaran. Guru dapat mengetahui masalah yang dihadapi selama proses pembelajaran melalui pengkajian pembelajaran sehingga dapat melakukan review terhadap kinerjanya yang selanjutnya dapat digunakan sebagai masukan untuk memperbaiki kinerjanya dan juga dapat meningkatkan kualitas pembelajaran. Salah satu cara pengkajian proses pembelajaran adalah melalui Lesson Study.

Lesson Study dilaksanakan dalam tiga tahapan yaitu Plan (merencanakan), Do (melaksanakan), dan See (merefleksi) yang berkelanjutan. Dengan kata lain Lesson Study merupakan suatu cara peningkatan mutu pendidikan yang tidak pernah berakhir. (continous improvement)
(Firman, dkk, 2007). Skema kegiatan Lesson Study diperlihatkan pada Gambar 1.

Peningkatan mutu pembelajaran melalui Lesson Study dimulai dengan tahap perencanaan (Plan). Pada tahap ini dilakukan identifikasi masalah yang ada di kelas untuk kegiatan Lesson Study dan perencanaan alternatif pemecahannya. Identifikasi masalah yang ada di kelas berkaitan dengan materi pokok yang relevan dengan kelas dan jadual pelajaran, karakteristik siswa dan suasana kelas, metode dan pendekatan pembelajaran, media, alat peraga, dan evaluasi proses dan hasil belajar. Rencana Pelaksanaan Pembelajaran (RPP) disusun secara kolaboratif, kemudian ditentukan seorang guru yang akan mengimplementasikannya pada Open Lesson (pelaksanaan pembelajaran).

Langkah kedua dalam Lesson Study adalah pelaksanaan pembelajaran (Do) melalui pelaksanaan Open Lesson. Dalam Open Lesson, guru model mengimplentasikan rancangan pembelajaran yang telah dirumuskan dalam perencanaan pembelajaran. Selama open lesson berlangsung, aktivitas siswa dalam proses pembelajaran diamati oleh observer atau pengamat. Observer mengamati seluruh aktivitas siswa selama proses pembelajaran dan mencatatnya pada lembar observasi untuk kemudian direfleksi. Selama pelaksanaan observasi, observer tidak diperkenankan mengganggu jalannya proses pembelajaran. 
Langkah ketiga dalam kegiatan Lesson Study adalah refleksi (See). Setelah selesai proses pembelajaran, dilakukan diskusi antara guru model dan observer yang dipandu oleh moderator untuk membahas proses pembelajaran yang dilaksanakan. Guru model mengawali diskusi dengan menyampaikan kesan-kesan dalam melaksanakan pembelajaran. Selanjutnya, observer diminta menyampaikan komentar dan Lesson Learnt dari proses pembelajaran terutama berkenaan dengan aktivitas siswa.

Pada prinsipnya, semua orang yang terlibat dalam kegiatan Lesson Study harus memperoleh Lesson Learnt. Dengan demikian, akan terbangun komunitas belajar melalui Lesson Study. Berdasarkan uraian tersebut di atas, penelitian ini bertujuan untuk meningkatkan kualitas pembelajaran kimia melalui Lesson Study pada materi hidrolisis garam dan Ksp.

Kualitas pembelajaran dalam penelitian ini dibatasi pada interaksi siswa, motivasi siswa, keaktifan siswa, dan keterlaksanaan proses pembelajaran oleh guru.

\section{Metode Penelitian}

Metode penelitian yang digunakan adalah metode penelitian deskriptif kualitatif denganmengimplementasikan tahapan lesson study, yaitu plan (merencanakan), do (melaksanakan), dan see (merefleksikan).

\section{a. Plan (merencanakan)}

Pada tahap plan, kegiatan yang dilakukan adalah :

1. Melakukan review silabus untuk mendapatkan kejelasan tujuan pembelajaran dan mencari ide-ide dari materi yang ada dalam buku pelajaran. Menganalisis karakteristik materi, siswa, model pembelajaran, media, alat peraga. Selanjutnya tim Lesson study berkolaborasi untuk menyusun rencana pelaksanaan pembelajaran.

2. Membuat lembar observasi berdasarkan indikator kualitas belajar, lembar LKS siswa, dan lembar evaluasi

3. Menentukan guru model yang akan mengimplementasikan rencana pelaksanaan pembelajaran yang telah disusun.

\section{b. Do (melaksanakan)}

Pada tahap do, kegiatan yang dilakukan adalah :

1. Guru model melaksanakan rencana pelaksanaan pembelajaran di kelas, sementara tim peneliti bertindak sebagai observer bersama dengan observer lain mengamati setiap aktivitas siswa selama proses pembelajaran dan mencatatnya pada lembar observasi. Observer tidak diperkenankan mengganggu jalannya proses pembelajaran. 
2. Pusat pembelajaran adalah siswa (student center), guru hanya bertindak sebagai fasilitator dan motivator.

3. Siswa menyimpulkan materi pembelajaran.

4. Guru memberikan penguatan atas kesimpulan siswa.

5. Pemberian kuisioner pada siswa pada tiap akhir open lesson.

6. Guru memberikan kegiatan tindak lanjut, sesuai indikator yang akan dicapai

c. See (merefleksikan)

Pada tahap see, kegiatan yang dilakukan adalah :

1. Guru model menyampaikan perasaan dan kesannya selama melakukan implementasi RPP pada proses pembelajaran yang dilaksanakan.

2. Observer memaparkan hasil pengamatan dari Open Lesson yang telah dilakukan.

3. Moderator menyimpulkan kekurangan yang terjadi pada Open Lesson yang telah dilakukan, namun tetap harus diberi penekanan bahwa semua masukan harus berpusat pada siswa dan sebagai evalusi diri untuk semua komunitas belajar.

Revisi RPP yang akan diimplementasikan pada Open Lesson berikutnya.

1. Hasil dan Pembahasan

Data penelitian diperoleh melalui observasi langsung dan pengisian kuesioner oleh siswa pada setiap akhir open lesson. Instrumen pada peneltian ini adalah lembar observasi berdasarkan indikator, lembar observasi bebas, dan kuesioner siswa pada akhir open lesson.

\section{a. Pertemuan I}

Perencanaan pembelajaran dilakukan oleh guru dan 4 orang observer sebelum Open Lesson dilaksanakan.

\section{Tahap Plan (merencanakan)}

Pada tahap plan (merencanakan), guru kimia dan 4 orang observer membuat Rencana Pelaksanaan Pembelajaran (RPP) secara bersamasama. Topik RPP pada pertemuan I adalah mengenai sifat garam yang terhidrolisis dalam air. Metode pembelajaran yang digunakan yaitu diskusi informasi, tanya jawab, dan resitasi (penugasan).

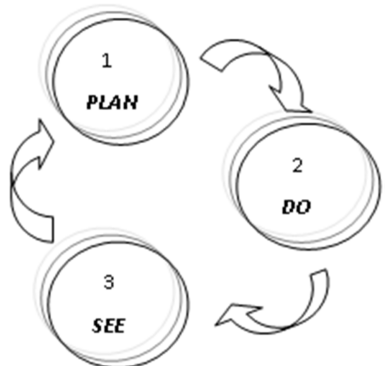

Gambar 1. danrefleksi (see). (Sumber : Firman, dkk, 2007). 


\section{Tahap Do (melaksanakan)}

Materi pokok yang dipelajari pada pertemuan I adalah hidrolisis garam. Submateri pokok yang dipelajari meliputi penentuan jenis garam yang terhidrolisis dalam air.

Kegiatan pembelajaran diawali dengan menginformasikan tujuan pembelajaran melalui indikator-indikator yang akan dicapai. Kemudian guru memimpin diskusi kelas untuk menggali pengetahuan siswa mengenai reaksi penggaraman dan sifatsifatnya. Siswa memerhatikan informasi yang disampaikan oleh guru, mencatat hal-hal yang dianggap penting, dan aktif dalam proses pembelajaran. Kegiatan pembelajaran diakhiri dengan simpulan mengenai jenis garam yang terhidrolisis dalam air oleh siswa.

Pada pelaksanaan pembelajaran ini, terlihat tidak semua siswa memperhatikan ketika guru memberikan contoh mengenai reaksi penggaraman dan juga terdapat beberapa siswa yang tidak mengerjakan LKS. Siswa yang duduk di bagian depan lebih aktif daripada siswa yang duduk di bagian belakang. Guru menunjuk siswa secara acak untuk mengerjakan soal di papan tulis. Pada saat siswa mengerjakan soal di papan tulis, sebagian besar siswa yang lainnya tidak memerhatikan dan membicarakan hal-hal di luar pembelajaran sehingga membuat suasana kelas tidak kondusif. Di akhir pembelajaran, guru membagikan kuesioner kepada siswa berkaitan dengan proses pembelajaran yang telah dilakukan.

\section{Tahap See (merefleksi)}

Setelah kegiatan pembelajaran selesai, guru kimia dan 4 orang observer lainnya memaparkan hasil pengamatan selama proses pembelajaran berlangsung. Pemaparan hasil pengamatan selama Open Lesson sangat bermanfaat untuk perbaikan pada proses pembelajaran selanjutnya. Aktivitas siswa yang diamati pada proses pembelajaran berkaitan dengan indikator penelitian, yaitu interaksi siswa, motivasi belajar siswa, keaktifan siswa, dan keterlaksanaan proses pembelajaran oleh guru. Hasil observasi tiap indikator dideskripsikan sebagai berikut :

(a) Interaksi antar siswa terlihat pada banyaknya siswa yang berdiskusi dengan siswa sebangkunya atau di luar siswa sebangku mengenai materi pelajaran. Interaksi antara siswa dengan guru terlihat dari banyaknya siswa yang menjawab pertanyaan yang diajukan guru dan siswa yang mengajukan pertanyaan kepada guru mengenai materi pembelajaran yang kurang dipahaminya. Interaksi siswa dengan sumber belajar masih sangat rendah karena hanya sebagian kecil siswa yang membaca buku untuk mencari jawaban atas soal yang diberikan oleh guru.

(b). Motivasi belajar siswa dapat dikatakan cukup baik karena seluruh siswa berada di kelas sebelum open lesson dimulai, seluruh siswa juga menyerahkan tugas tepat waktu, 
namun banyak siswa yang tidak memperhatikan dan membicarakan hal-hal lain di luar pembelajaran dengan siswa lain pada saat guru menjelaskan materi pelajaran, terutama siswa yang duduk di bagian belakang.

(c). Selama proses pembelajaran, keaktifan siswa sangat rendah, tidak ada siswa yang menyatakan pendapat pada saat berdiskusi dan hanya sebagian kecil siswa yang mengerjakan soal latihan yang diberikan guru dan mengerjakannya di papan tulis.

(d).Keterlaksanaanproses pembelajaran oleh guru dapat dikatakan baik. Guru model menguasai materi pokok yang diajarkan, guru model melaksanakan proses pembelajaran sesuai dengan RPP kolaborasi, guru model juga menegur siswa yang membuat suasana kelas menjadi tidak kondusif untuk belajar.

Pada lembar observasi bebas, diperoleh informasi bahwa siswa nomor 9 dan 10 asyik memainkan kartu tanda pengenal siswa pada menit ke-5, siswa nomor 5 mulai mengantuk pada menit ke-30, siswa nomor 4 mulai mengantuk pada menit ke-60, siswa nomor 6 memainkan handphone pada menit ke-70, dan siswa nomor 10 menyanyi pada menit ke-70. Siswa no 9, 10, dan 6 adalah siswa yang duduk di bagian belakang.
Berdasarkan pemaparan di atas, kekurangan yang terjadi pada proses pembelajaran pada pertemuan I diantaranya :

1) Keaktifan siswa dengan siswa selama proses pembelajaran berlangsung masih kurang.

2) Guru kurang memantau siswa yang duduk di bagian belakang sehingga pada saat proses pembelajaran berlangsung sebagian siswa yang duduk di bagian belakang sering berinteraksi dengan siswa lainnya dan membuat suasana kelas kurang kondusif.

\section{b. Pertemuan II}

Pada pertemuan kedua, submateri pokok yang dipelajari adalah penentuan $\mathrm{pH}$ larutan garam yang terhidrolisis. Perencanaan pembelajaran dilakukan oleh guru dan 4 orang observer sebelum Open Lesson dilaksanakan.

\section{Tahap Plan (merencanakan)}

Seperti pada pertemuan pertama, peneliti, guru kimia, dan observer membuat Rencana Pelaksanaan Pembelajaran (RPP) secara bersamasama. Perencanaan didasarkan pada hasil refleksi pada pertemuan pertama. Topik RPP pada pertemuan II adalah mengenai $\mathrm{pH}$ larutan garam yang terhidrolisis dalam air. Metode pembelajaran yang digunakan berdasarkan RPP kolaborasi adalah diskusi informasi, diskusi kelompok, dan problem solving, sedangkan metode pembelajaran yang digunakan adalah 
Active Learning yang bertujuan untuk meningkatkan keaktifan siswa. Kegiatan pembelajaran menggunakan media berupa Lembar Kerja Siswa (LKS) yang dihasilkan melalui kolaborasi agar siswa dapat berdiskusi dengan siswa lainnya, sehingga interaksi, motivasi belajar, dan keaktifan siswa dalam proses pembelajaran dapat meningkat.

\section{Tahap Do (melaksanakan)}

Kegiatan pembelajaran diawali dengan menginformasikan tujuan pembelajaran melalui indikator-indikator yang akan dicapai. Kemudian guru memimpin diskusi kelas untuk mengingatkan kembali macam-macam garam terhidrolisis. Guru membagi siswa ke dalam 6 kelompok secara acak dan membagikan LKS kepada masing-masing kelompok untuk didiskusikan. Guru menunjuk perwakilan dari masing-masing kelompok untuk mengerjakan soal yang telah didiskusikan di papan tulis kemudian memberikan penguatan atas jawaban siswa. Kegiatan pembelajaran diakhiri dengan simpulan mengenai perhitungan $\mathrm{pH}$ pada garam terhidrolisis oleh siswa.

Tidak semua siswa aktif berdiskusi dalam mengerjakan soal yang terdapat pada LKS dalam kelompoknya masingmasing. Saat siswa berdiskusi untuk mengerjakan LKS, guru berkeliling dan memantau aktivitas siswa, yang merupakan perbaikan dari Open Lesson I. Guru menanyakan perkembangan dan kesulitan yang dihadapi siswa dalam mengerjakan LKS. Namun, tidak seluruh kelompok dapat terpantau kegiatannya. Ada beberapa kelompok yang tidak melakukan diskusi dengan baik dan tidak terpantau oleh guru. Guru terlihat kurang tegas menanggapi beberapa siswa yang kurang serius dalam belajar. Pada saat perwakilan dari masing-masing kelompok mengerjakan soal di papan tulis, beberapa siswa yang lainnya lebih tertarik berinteraksi dengan temannya membicarakan hal-hal di luar pembelajaran sehingga membuat suasana kelas kurang kondusif. Di akhir pembelajaran, guru membagikan kuesioner kepada siswa berkaitan dengan proses pembelajaran yang telah dilakukan.

\section{Tahap See (merefleksi)}

Jika dilihat dari indikator kualitas pembelajaran yang pertama, yaitu interaksi siswa, pada lembar hasil observasi proses pembelajaran dapat dideskripsikan bahwa selama proses pembelajaran, terjadi interaksi antara siswa dengan siswa lainnya, antara siswa dengan guru, maupun antara siswa dengan sumber belajar. Hasil analisis masing-masing indikator kualitas pembelajaran berdasarkan pada hasil observasi yang dilakukan menunjukkan bahwa:

(a). Interaksi antarsiswa terlihat pada banyaknya siswa yang berdiskusi dengan siswa sebangkunya atau di luar siswa sebangku mengenai materi pelajaran. Interaksi antara siswa dengan guru terlihat dari banyaknya siswa yang menjawab 
pertanyaan yang diajukan guru dan siswa yang mengajukan pertanyaan kepada guru mengenai materi pembelajaran yang kurang dipahaminya. Interaksi siswa dengan sumber belajar terlihat dari siswa yang membaca buku untuk mencari jawaban atas soal yang diberikan oleh guru. Interaksi siswa yang terjadi pada Open Lesson II lebih banyak daripada Open Lesson I karena pada Open Lesson II digunakan metode diskusi kelompok dan problem solving.

(b). Motivasi belajar siswa dapat dikatakan baik karena seluruh siswa berada di kelas sebelum Open Lesson dimulai, seluruh siswa juga menyerahkan tugas tepat waktu. Motivasi belajar siswa dapat dikatakan mengalami peningkatan dari Open Lesson I karena siswa yang tidak memperhatikan dan membicarakan hal-hal lain di luar pembelajaran dengan siswa lain pada saat guru menjelaskan materi pelajaran lebih sedikit. Sebagian besar siswa memerhatikan pada saat guru menjelaskan materi pembelajaran sebelum diskusi kelompok dimulai, namun ada beberapa siswa yang tidak berdiskusi dengan baik dan membicarakan halhal lain di luar pembelajaran dengan teman sekelompoknya selama proses pembelajaran, terutama pada kelompok di bagian belakang karena

$\begin{array}{lll}\text { guru tidak } & \text { memantau } & \text { semua } \\ \text { kelompok } & \text { selama } & \text { proses } \\ \text { pembelajaran. } & & \end{array}$

(c). Keaktifan siswa mengalami peningkatan dari Open Lesson I karena sebagian besar siswa aktif berdiskusi untuk mengerjakan soal yang diberikan oleh guru dan masing-masing perwakilan kelompok mengerjakan soal di papan tulis.

(d).Keterlaksanaanproses pembelajaran oleh guru dapat dikatakan baik. Guru menguasai materi pokok yang diajarkan, guru melaksanakan proses pembelajaran sesuai dengan RPP kolaborasi, guru juga menegur siswa yang membuat suasana kelas menjadi tidak kondusif untuk belajar, namun tidak semua kelompok dapat terpantau oleh guru selama proses pembelajaran.

Pada lembar observasi bebas, diperoleh informasi bahwa siswa nomor 10 mulai kipas-kipas pada menit ke-50, siswa nomor 24 mulai kipas-kipas pada menit ke-60, dan siswa nomor 5 mulai mengantuk pada menit ke-65. Siswa nomor 5 adalah siswa yang kelompoknya terdapat di bagian belakang.

Berdasarkan pemaparan di atas, kekurangan yang terjadi pada proses pembelajaran pada pertemuan II adalah pengelolaan kelas belum berlangsung optimal sehingga beberapa siswa terlihat masih ada yang kurang serius dalam proses pembelajaran. 


\section{c. Pertemuan III}

Pada pertemuan ketiga, submateri pokok yang dipelajari adalah penentuan ciri-ciri beberapa jenis garam yang terhidrolisis dalam air. Perencanaan pembelajaran dilakukan oleh guru dan 4 orang observer sebelum Open Lesson dilaksanakan.

\section{Tahap Plan (merencanakan)}

Seperti pada pertemuan sebelumnya, tim peneliti, guru kimia, dan observer membuat Rencana Pelaksanaan Pembelajaran (RPP) secara bersamasama. Perencanaan didasarkan pada hasil refleksi pada pertemuan I dan pertemuan II. Topik RPP pada pertemuan III adalah mengenai penentuan ciri-ciri beberapa jenis garam yang terhidrolisis dalam air. Pendekatan pembelajaran yang digunakan berdasarkan RPP kolaborasi adalah Inquiry sedangkan metode pembelajaran yang digunakan adalah diskusi informasi, pemberian tugas, dan praktikum. Praktikum dilaksanakan secara berkelompok dengan jumlah anggota kelompok yang lebih sedikit dibandingkan dengan Open Lesson II agar pengelolaan kelas dapat lebih baik. Kegiatan pembelajaran menggunakan media berupa alat-alat praktikum dan Lembar Kerja Siswa (LKS) yang dihasilkan melalui kolaborasi agar siswa dapat berdiskusi dengan siswa lainnya sehingga interaksi, motivasi belajar, dan keaktifan siswa dalam proses pembelajaran diharapkan dapat meningkat.

\section{Tahap Do (melaksanakan)}

Kegiatan pembelajaran diawali dengan menginformasikan tujuan pembelajaran melalui indikator-indikator yang akan dicapai. Kemudian guru memimpin diskusi kelas untuk mengingatkan kembali macam-macam garam terhidrolisis. Guru membagi siswa ke dalam 8 kelompok dan membagikan LKS hasil kolaborasi pada masing-masing kelompok. Siswa aktif melakukan kegiatan praktikum sesuai dengan petunjuk dan menjawab pertanyaan yang terdapat pada LKS. Kegiatan pembelajaran diakhiri dengan simpulan mengenai ciri-ciri garam yang terhidrolisis dalam air. Sebelum memulai kegiatan praktikum, suasana kelas sangat gaduh karena perwakilan dari semua kelompok mengambil alat dan bahan praktikum secara bersamaan sedangkan siswa yang lain berinteraksi dalam kelompoknya masing-masing dan membicarakan hal-hal di luar pembelajaran, namun guru segera meminta siswa untuk tenang sehingga kelas kembali kondusif.

Saat siswa melakukan praktikum, guru berkeliling dan memantau aktivitas siswa pada setiap kelompok, yang merupakan perbaikan dari Open Lesson I dan II. Guru menanyakan perkembangan dan kesulitan yang dihadapi siswa dalam melakukan praktikum. Setelah kegiatan praktikum, guru menugaskan kepada masing-masing kelompok untuk membuat laporan praktikum sesuai dengan data yang diperoleh dan akan dikumpulkan 
pada pertemuan berikutnya. $\mathrm{Di}$ akhir pembelajaran, guru membagikan kuesioner kepada siswa berkaitan dengan proses pembelajaran yang telah dilakukan.

\section{Tahap See (merefleksi)}

Hasil observasi para observer pada open lesson ke tiga memberikan informasi bahwa indikator kualitas pembelajaran semuanya dapat terlaksana. Deskripsi masing-masing indikator kualitas pembelajaran adalah sebagai berikut :

(a). Interaksi antarsiswa terlihat pada banyaknya siswa yang berdiskusi dengan siswa sebangkunya atau di luar siswa sebangku mengenai materi pelajaran. Interaksi antara siswa dengan guru terlihat dari banyaknya siswa yang menjawab pertanyaan yang diajukan guru dan siswa yang mengajukan pertanyaan kepada guru mengenai materi pembelajaran yang kurang dipahaminya. Interaksi siswa dengan sumber belajar terlihat dari siswa yang membaca buku untuk mencari jawaban atas pertanyaan yang terdapat pada LKS dan menyesuaikan hasil eksperimen dengan teori yang terdapat pada buku. Interaksi siswa yang terjadi lebih banyak daripada Open Lesson | dan || karena pada Open Lesson III digunakan metode praktikum.

(b). Berdasarkan lembar hasil observasi proses pembelajaran dapat dideskripsikan bahwa selama proses pembelajaran, motivasi belajar siswa dapat dikatakan baik karena seluruh siswa berada di kelas sebelum Open Lesson dimulai, seluruh siswa juga menyerahkan tugas tepat waktu. Motivasi belajar siswa dapat dikatakan mengalami peningkatan dari Open Lesson I dan II karena siswa yang tidak memperhatikan dan membicarakan hal-hal lain di luar pembelajaran dengan siswa lain pada saat melakukan kegiatan praktikum lebih sedikit. Peningkatan ini dikarenakan siswa menyukai metode praktikum yang digunakan pada pertemuan ketiga sehingga lebih termotivasi dalam proses pembelajaran.

(c). Selama proses pembelajaran, keaktifan siswa mengalami peningkatan dari Open Lesson I dan II karena sebagian besar siswa aktif melakukan kegiatan praktikum dan berdiskusi dalam kelompoknya masing-masing untuk menjawab pertanyaan yang terdapat pada LKS.

(d). Keterlaksanaan proses pembelajaran oleh guru dapat dikatakan baik. Guru menguasai materi pokok yang diajarkan, guru melaksanakan pembelajaran sesuai dengan RPP kolaborasi, guru juga berkeliling untuk memantau aktivitas siswa dalam setiap kelompok selama proses pembelajaran.

Pada lembar observasi bebas, diperoleh informasi bahwa pada menit ke- 
1 hingga menit ke-10, siswa nomor 9, 10, 19, 20, dan 28 belajar mengenai mata pelajaran biologi. Namun pada saat praktikum dimulai siswa-siswa tersebut terlihat aktif dalam melakukan praktikum dan diskusi tentang materi yang sedang dibahas.

Berdasarkan pemaparan di atas, kekurangan yang terjadi pada proses pembelajaran pada pertemuan III adalah guru tidak meminta perwakilan dari masing-masing kelompok untuk mengambil alat dan bahan praktikum secara bergantian sehingga kelas menjadi gaduh sebelum praktikum dimulai.

\section{d. Pertemuan IV}

Pada pertemuan IV tidak dilakukan open lesson, namun siswa mengerjakan tes hasil belajar untuk materi Hidrolisis Garam selama 60 menit. Tes hasil belajar dilakukan untuk mengetahui pemahaman siswa terhadap materi Hidrolisis Garam.

\section{e. Pertemuan V}

Pada pertemuan kelima, submateri pokok yang dipelajari adalah pengaruh penambahan ion sejenis, penentuan $\mathrm{pH}$ berdasarkan nilai Ksp, dan meramalkan endapan berdasarkan nilai Ksp. Perencanaan pembelajaran dilakukan oleh guru dan 4 orang observer sebelum Open Lesson dilaksanakan.

\section{Tahap Plan (merencanakan)}

Seperti pada pertemuan sebelumnya, tim peneliti, guru kimia, dan observer membuat Rencana Pelaksanaan Pembelajaran (RPP) secara bersamasama. Perencanaan didasarkan pada hasil refleksi pada pertemuan I, II, dan III. Topik RPP pada Open Lesson IV adalah mengenai penambahan ion sejenis, penentuan $\mathrm{pH}$ berdasarkan nilai $\mathrm{Ksp}$, dan meramalkan endapan berdasarkan nilai Ksp. Pendekatan pembelajaran yang digunakan berdasarkan RPP kolaborasi adalah Active Learning sedangkan metode pembelajaran yang digunakan adalah diskusi kelompok dan pemberian tugas dengan model pembelajaran Number Head Together (NHT). Kegiatan pembelajaran menggunakan media berupa laptop, LCD dan Lembar Kerja Siswa (LKS) yang dihasilkan melalui kolaborasi agar siswa dapat berdiskusi dengan siswa lainnya sehingga interaksi, motivasi belajar, dan keaktifan siswa dalam proses pembelajaran dapat meningkat.

\section{Tahap Do (melaksanakan)}

Kegiatan pembelajaran yang dilakukan pada Open Lesson IV sesuai dengan RPP yang disusun melalui kolaborasi seperti tahap sebelumnya. Kegiatan pembelajaran diawali dengan menginformasikan tujuan pembelajaran melalui indikator-indikator yang akan dicapai. Kemudian guru memimpin diskusi kelas untuk mengungkap pengetahuan siswa mengenai tetapan hasil kali kelarutan. Guru membagi siswa ke dalam 8 kelompok dan membagikan LKS kepada masing-masing kelompok untuk didiskusikan. Diskusi kelompok tersebut 
menerapkan model pembelajaran Number Head Together (NHT). Setelah diskusi selesai, guru menunjuk perwakilan dari masing-masing kelompok secara acak untuk mengerjakan soal hasil diskusi di papan tulis. Kegiatan pembelajaran diakhiri dengan tes hasil belajar untuk mengetahui ketercapaian indikator dan kompetensi. Sebelum memulai diskusi, suasana kelas sangat gaduh karena masing-masing kelompok berdebat mengenai pemilihan ketua kelompok, namun guru segera meminta siswa untuk tenang sehingga kelas kembali kondusif.

Saat siswa berdiskusi, guru berkeliling dan memantau aktivitas siswa pada setiap kelompok, yang merupakan perbaikan dari Open Lesson I, II, dan III. Guru menanyakan perkembangan dan kesulitan yang dihadapi siswa dalam mengerjakan soal yang terdapat pada LKS. Setelah berdiskusi, guru meminta kepada masing-masing kelompok untuk mengumpulkan hasil diskusi dan menunjuk secara acak perwakilan dari masing-masing kelompok untuk mengerjakan soal di papan tulis. Ketua kelompok bertanggung jawab terhadap kelompoknya apabila perwakilan kelompoknya kurang tepat dalam mengerjakan soal di papan tulis. Pada akhir pembelajaran, tidak ada perwakilan kelompok yang kurang tepat dalam mengerjakan soal. Di akhir pembelajaran, guru membagikan kuesioner kepada siswa berkaitan dengan proses pembelajaran yang telah dilakukan.

\section{Tahap See (merefleksi)}

Jika dilihat dari indikator kualitas pembelajaran maka masing-masing indikator pada pelaksnaan open lesson ke empat adalah sebagai berikut :

(a). Interaksi siswa, pada lembar hasil observasi proses pembelajaran dapat dideskripsikan bahwa selama proses pembelajaran, terjadi interaksi antara siswa dengan siswa lainnya, antara siswa dengan guru, maupun antara siswa dengan sumber belajar. Interaksi antarsiswa terlihat pada banyaknya siswa yang berdiskusi dengan siswa sebangkunya atau di luar siswa sebangku mengenai materi pelajaran. Interaksi antara siswa dengan guru terlihat dari banyaknya siswa yang menjawab pertanyaan yang diajukan guru dan siswa yang mengajukan pertanyaan kepada guru mengenai materi pembelajaran yang kurang dipahaminya. Interaksi siswa dengan sumber belajar terlihat dari siswa yang membaca buku untuk mencari jawaban atas soal latihan yang diberikan oleh guru. Interaksi yang terjadi lebih banyak daripada Open Lesson I, II, dan III karena pada pertemuan kelima digunakan model pembelajaran Number Head Together (NHT).

(b). Selama proses pembelajaran, motivasi belajar siswa dapat dikatakan baik karena seluruh siswa berada di kelas sebelum Open 
Lesson dimulai, seluruh siswa juga menyerahkan tugas tepat waktu. Motivasi belajar siswa dapat dikatakan mengalami peningkatan dari Open Lesson I, II, dan III karena siswa yang tidak memerhatikan dan membicarakan halhal lain di luar pembelajaran dengan siswa lain pada saat diskusi lebih sedikit. Peningkatan ini dikarenakan pada pertemuan kelima digunakan model pembelajaran Number Head Together (NHT) sehingga siswa tidak jenuh selama proses pembelajaran.

(c). Keaktifan siswa mengalami peningkatan dari Open Lesson I, II, dan III karena semua siswa aktif berdiskusi dalam kelompoknya masing-masing untuk menjawab soal yang diberikan oleh guru.

(d).Keterlaksanaanproses pembelajaran oleh guru selama proses pembelajaran dapat dikatakan baik. Guru menguasai materi pokok yang diajarkan, guru melaksanakan proses pembelajaran sesuai dengan RPP kolaborasi, guru juga berkeliling untuk memantau aktivitas siswa dalam setiap kelompok selama proses pembelajaran.

Berdasarkan lembar observasi bebas, diperoleh informasi bahwa siswa nomor 28 meniup-niup pipet pada menit ke-45, siswa nomor 2 mengantuk pada menit ke-65, dan siswa nomor 31 dan 27 terlihat berjalan-jalan pada menit ke-55.
Berdasarkan pemaparan di atas, kekurangan yang terjadi pada proses pembelajaran pada pertemuan $\mathrm{V}$ adalah guru tidak menentukan ketua dari masing-masing kelompok sehingga kelas menjadi gaduh sebelum proses pembelajaran dimulai. Hal ini dapat dijadikan masukan untuk pembagian kelompok diskusi pada proses pembelajaran yang lainnya.

\section{f. Pertemuan VI}

Pada pertemuan VI tidak dilakukan open lesson, namun siswa mengerjakan tes hasil belajar untuk materi Kelarutan dan Hasil Kali Kelarutan selama 60 menit. Berdasarkan hasil observasi para observer dan pengisian kuesioner siswa pada setiap akhir open lesson diperoleh data bahwa masing-masing indikator kualitas pembelajaran yang terdiri dari interaksi siswa, motivasi belajar siswa, keaktifan siswa, dan keterlaksanaan proses pembelajaran oleh guru mengalami peningkatan dari open lesson I hingga open lesson IV. Di samping itu, diperoleh juga informasi bahwa nilai rata-rata tes hasil belajar siswa mengalami peningkatan dari tes hasil belajar pada materi hidrolisis garam sebesar 62,03 menjadi 69,05 pada materi kelarutan dan hasil kali kelarutan (Ksp). Dengan demikian, dapat dikatakan bahwa kualitas pembelajaran kimia yang dilakukan di $\begin{array}{llll}\text { SMA } & \mathrm{N} & 7 & \text { Tangerang mengalami }\end{array}$ peningkatan. Grafik peningkatan kualitas pembelajaran hasil analisis dan pengolhan data disjikan pada gambar 2 . 


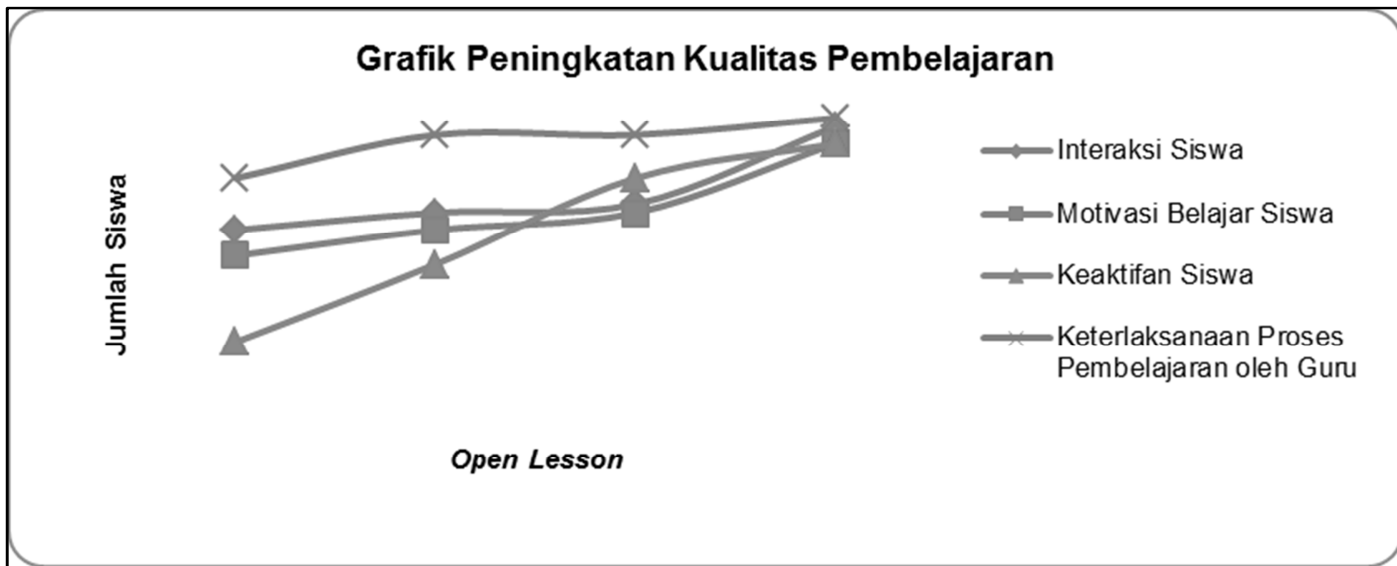

Gambar 2. Grafik Peningkatan Kualitas Pembelajaran Hidrolisis garam dan Ksp pada setiap Open Lesson.

Indikator interaksi siswa meningkat dari pertemuan pertama sampai pertemuan ke empat. Indikator motivasi dan keterlaksanaan proses pembelajaran oleh guru pada pertemuan 1-3 mengalami peningkatan, dan secara signifikan sangat meningkat pada pertemuan ke empat. Indicator keaktifan siswa secara signifikan meningkat tajam mulai pertemuan 1 sampai ke empat.

\section{Kesimpulandan Saran \\ a. Kesimpulan}

Kualitas pembelajaran yang meliputi interaksi siswa, motivas ibelajar siswa, keaktifan siswa dalam proses pembelajaran, dan keterlaksanaan oleh guru dalam proses pembelajaran mengalami peningkatan melalui implementasi lesson study. Peningkatan kualitas pembelajaran kimia siswa se cara nyata terlihat dari perolehan nilai tes hasil belajar siswa pada materi hidrolisis garam dan Ksp yang mengalami peningkatan dari 62,03 menjadi 69,05.

\section{b. Saran}

Penelitian berikutnya disarankan implementasi pelaksanaan proses pembelajaran melalui lesson study berbasis sekolah dengan kolaborasi guru dapat dilaksnakan untuk materi-materi kimia lainnya. Kaloborasi juga dapat dilakukan berbasis pada Musyawarah Guru Mata Pelajaran (MGMP), sehingga pembentukan komunitas belajar diantara guru, perguruan tinggi dan masyarakat sekolah lainnyaakansemakinnyata. 
DAFTAR PUSTAKA

Firman, Harry, dkk. 2007. Lesson Study

SuatuStrategiuntukMeningkatkanKeprofesionalanPendidik. Bandung: UPI Press.

Senjaya, Wina. 2008. StrategiPembelajaran; BerorientasiStandar Proses Pendidikan. Jakarta: KencanaPrenada Media Group.

Syah, Muhibbin. 2008. Psikologi Pendidikan dengan Pendekatan Baru. Bandung: PT. RemajaRosdakarya.

Sukmadinata, Nana Syaodih. 2007. MetodePenelitianPendidikan. Bandung : Remaja Rodsakarya.

Sudjana, Nana. 2004. PenilaianHasilProsesBelajarMengajar. Bandung : PT. RemajaRosdakarya.

Senjaya, Wina. 2008. StrategiPembelajaran; BerorientasiStandarProsesPendidikan. Jakarta: KencanaPrenada Media Group

Usman, Uzer. 2002. MenjadiGuru Profesional. Bandung: PT. RemajaRosdakarya 